\title{
TOURISM AS A SOURCE OF TAXATION - THE PORTUGUESE CASE
}

\author{
Carlos Rodrigues ${ }^{1}$ \\ Ana Campina ${ }^{2}$
}

DOI: https://doi.org/10.31410/tmt.2020.97

\begin{abstract}
This research analyzes the financial contribution generated by the activity of tourism to the general budget of the state of Portugal through the taxes collected on the profits of companies linked to tourism and on VAT that tourists pay in Portugal. We concluded, in the end, that the financial values generated for the state budget are of great importance and have been growing.
\end{abstract}

Keywords: Tourism, Taxes, Portuguese national budget, VAT, Corporate income tax.

\section{INTRODUCTION}

$\mathrm{T}$ he phenomenon of world tourism has been growing worldwide and with it, all the economic evolution is supported by the multiple activities that support it. This study aims to understand how tourism in Portugal generates tax revenues that contribute to obtaining income for the annual budgets of the Portuguese state (J.J. Gomes Canotilho \& Vital Moreira, 2007 p. 1088).

The methodology applied to this analysis focuses only on two taxes and is exclusively supported by statistical data from highly credible institutions in Portugal. Thus, we can identify it as a mixed methodology (qualitative and quantitative), using research, analysis, and interpretation of scientific data.

\section{THE PANORAMA OF TOURISM IN PORTUGAL - STATISTICAL ANALYSIS}

Tourism in Portugal has been growing, a fact that has great implications for the balance of transactions, so this subject is being analyzed as a percentage of the Gross Domestic Product - GDP - national or in monetary values.

Pay attention to "Table l" to realize that concerning the Portuguese GDP, the monetary balance - in millions of Euros - between the amounts collected within tourism entering Portugal and that "goes" from Portugal to other parts of the world, is favorable to Portuguese coffers between 5,171.99 million Euros in 2011 and 13,130.87 million Euros in 2019, meaning there was a positive increase of $253.88 \%$ in an eight-year period, which represented $6.2 \%$ of the national GDP.

Table 1.

\begin{tabular}{|c|c|c|c|c|c|c|}
\hline \multirow{2}{*}{ Years } & \multicolumn{3}{|c|}{ Travel and Tourism Balance as \% of GDP } & \multicolumn{3}{c|}{$\begin{array}{c}\text { Balance between exports and imports of } \\
\text { Travel and Tourism - in millions of Euros }\end{array}$} \\
\cline { 2 - 7 } & Balance & Exports & Imports & Balance & Exports & Imports \\
\hline 2011 & 2,9 & 4,6 & 1,7 & $5.171,99$ & $8.145,56$ & $2.973,57$ \\
\hline 2012 & 3,4 & 5,1 & 1,8 & $5.659,57$ & $8.605,54$ & $2.945,97$ \\
\hline
\end{tabular}

IJP - Instituto Jurídico Portucalense, Porto, Portugal

IJP - Instituto Jurídico Portucalense, Porto, Portugal 


\begin{tabular}{|l|l|c|c|c|c|c|}
\hline 2013 & 3,6 & 5,4 & 1,7 & $6.218,29$ & $9.156,98$ & $2.938,69$ \\
\hline 2014 & 4,1 & 5,9 & 1,8 & $7.156,89$ & $10.284,20$ & $3.127,32$ \\
\hline 2015 & 4,6 & 6,5 & 1,9 & $8.272,63$ & $11.605,21$ & $3.332,58$ \\
\hline 2016 & 5,0 & 6,9 & 1,9 & $9.261,18$ & $12.811,41$ & $3.550,23$ \\
\hline 2017 & 5,9 & 7,9 & 2,1 & $11.500,36$ & $15.550,37$ & $4.050,01$ \\
\hline 2018 & 6,1 & 8,3 & 2,2 & $12.469,11$ & $17.053,55$ & $4.584,44$ \\
\hline 2019 & 6,2 & 8,6 & 2,5 & $13.130,87$ & $18.430,72$ & $5.299,86$ \\
\hline
\end{tabular}

Source - PORDATA - https://www.pordata.pt/DB/Portugal/Ambiente+de+Consulta/Tabela

\subsection{Analysis of the number of the accommodation establishments}

When we started to analyze the source of establishments dedicated to tourist accommodation, namely, hotels, inns, guest houses, and local accommodation, in 2019 Portugal had 6.833 units, see "Table 2", special attention is given to the North of Portugal with 1.785 units, and the metropolitan area of the capital - Lisbon with 1.155 units. These figures are a reflection of the exponential growth that Portugal has experienced, especially in the last decade, the growth of tourism in Portugal.

Table 2. Establishments by type and regions - Units: Number

\begin{tabular}{|l|c|c|c|c|}
\hline REGION & $\begin{array}{c}\text { Total of Touristic } \\
\text { Accommodation }\end{array}$ & $\begin{array}{c}\text { Total } \\
\text { Hotel Trade }\end{array}$ & $\begin{array}{c}\text { Total } \\
\text { TA e THT }\end{array}$ & Local Housing \\
\hline PORTUGAL & $\mathbf{6 ~ 8 3 3}$ & $\mathbf{1 9 2 3}$ & $\mathbf{1 ~ 6 8 7}$ & $\mathbf{3 2 2 3}$ \\
\hline CONTINENTE & $\mathbf{6 ~ 0 4 8}$ & $\mathbf{1 6 7 9}$ & $\mathbf{1 5 2 2}$ & $\mathbf{2 8 4 7}$ \\
\hline North & 1785 & 419 & 641 & 725 \\
\hline Center & 1365 & 381 & 400 & 584 \\
\hline MA Lisbon & 1155 & 338 & 23 & 794 \\
\hline Alentejo & 753 & 132 & 355 & 266 \\
\hline Algarve & 990 & 409 & 103 & 478 \\
\hline AR AZORES & $\mathbf{4 0 4}$ & $\mathbf{1 0 0}$ & $\mathbf{1 0 8}$ & $\mathbf{1 9 6}$ \\
\hline AR MADEIRA & $\mathbf{3 8 1}$ & $\mathbf{1 4 4}$ & $\mathbf{5 7}$ & $\mathbf{1 8 0}$ \\
\hline
\end{tabular}

Source - Instituto Nacional de Estatística - Estatísticas do Turismo: 2019. Lisboa: INE, 2020.

Available url:https://www.ine.pt/xurl/pub/133574 ISSN 0377-2306. ISBN 978-989-25-0542-8

\subsection{Analysis of income generated by accommodation establishments}

Regarding the level of billing generated by accommodation establishments in Portugal, which therefore contribute greatly to the balance of exports in Portugal, in relation to 2019, it is shown in "Table 3" below, which shows us the total amount of earnings generated by those establishments amounted to 4,295,814 TEUR.

It should be noted that the "Metropolitan Area of the city of Lisbon" stood out with 1,372,192 TEUR, followed closely by the "Algarve" with 1,225,746 TEUR.

Table 3. Total Income by type of establishments and by regions - Units: Thousand euros

\begin{tabular}{|l|l|l|l|r|l|l|l|}
\hline Region & $\begin{array}{l}\text { GLOBAL } \\
\text { TOTAL } \\
\text { Touristic } \\
\text { Accommoda- } \\
\text { tions }\end{array}$ & $\begin{array}{l}\text { Total Hotel } \\
\text { Business }\end{array}$ & $\begin{array}{l}\text { Total Tour- } \\
\text { istic Apart- } \\
\text { ments }\end{array}$ & $\begin{array}{l}\text { Total Touris- } \\
\text { tic Villages }\end{array}$ & $\begin{array}{l}\text { Total Guest- } \\
\text { houses and } \\
\text { Farms in } \\
\text { Madeira } \\
\text { Island }\end{array}$ & $\begin{array}{l}\text { Total TER - } \\
\text { Tourism in } \\
\text { Rural Area } \\
\text { and TH }- \\
\text { Housing } \\
\text { Tourism }\end{array}$ & $\begin{array}{l}\text { Total } \\
\text { AL-Local } \\
\text { Accommoda- } \\
\text { tion }\end{array}$ \\
\hline PORTUGAL & $\mathbf{4 2 9 5 8 1 4}$ & $\mathbf{3 7 9 5 4 7 0}$ & $\mathbf{1 8 3 0 6 5}$ & $\mathbf{1 3 8 6 0 2}$ & $\mathbf{7 9 6 8 3}$ & $\mathbf{1 1 8 7 1 1}$ & $\mathbf{3 8 1 6 3 4}$ \\
\hline CONTINENTE: & $\mathbf{3 7 7 1 ~ 2 4 2}$ & $\mathbf{3 3 1 0 7 2 8}$ & $\mathbf{1 7 1 ~ 0 1 6}$ & $\mathbf{. .}$ & $\mathbf{5 8 9 9 8}$ & $\mathbf{1 0 5 5 2 9}$ & $\mathbf{3 5 4 9 8 6}$ \\
\hline 1-North & 642935 & 527571 & 4771 & 2323 & 15716 & 35487 & 79877 \\
\hline
\end{tabular}




\begin{tabular}{|l|r|r|r|r|r|r|r|}
\hline 2-Center & 355414 & 286503 & 2806 & 8216 & 9303 & 24011 & 44900 \\
\hline 3-MA Lisboa & 1372192 & 1216794 & 22224 & 14927 & 18474 & 2036 & 153362 \\
\hline 4-Alentejo & 174956 & 125931 & 4774 & $\ldots$ & 9273 & 32328 & 16697 \\
\hline 5-Algarve & 1225746 & 1153929 & 136441 & 104487 & 6232 & 11666 & 60151 \\
\hline AR AZORES & $\mathbf{1 1 7 1 1 5}$ & $\mathbf{1 0 4 5 1 2}$ & $\mathbf{6 7 4 0}$ & $\ldots$ & $\ldots$ & $\mathbf{4 1 9 3}$ & $\mathbf{8 4 1 0}$ \\
\hline AR MADEIRA & $\mathbf{4 0 7 4 5 7}$ & $\mathbf{3 8 0 ~ 2 2 9}$ & $\mathbf{5 3 0 9}$ & $\ldots$ & $\ldots$ & $\mathbf{8 9 8 9}$ & $\mathbf{1 8 2 3 8}$ \\
\hline
\end{tabular}

Source - Instituto Nacional de Estatística - Estatísticas do Turismo: 2019. Lisboa: INE, 2020. Available www url:https://www.ine.pt/xurl/pub/133574 ISSN 0377-2306. ISBN 978-989-25-0542-8

These Tables give us a perspective of the importance of tourism in Portugal, showing us that these services have generated, and continue to generate, in Portugal a great source of monetary income for the country.

\section{TAX REVENUE GENERATED BY TOURISM - STATISTICAL ANALYSIS}

The aspects we have shown above, on the monetary importance, and not only, of tourism in Portugal, now leads us to analyze the importance that tourism has to generate revenue through taxes for the annual budget of the Portuguese State (José Joaquim Teixeira Ribeiro, 1997, p. 49).

In this respect, we will look at two taxes in particular. Firstly, we are going to analyze the "Corporate Income Tax - IRC" paid by corporate companies (J.J. Gomes Canotilho \& Vital Moreira, 2007 p. 1100) in the area of "Accommodation, Restaurants and Similar", that is, concerning the tax profit that these companies have annually, we will proceed to analysis through the statistical data contained in the database of the Portuguese Tax and Customs Authority - AT, to understand how much these business companies contributed to this income tax in the 2016 to 2018 three-year period. The triennial analysis relates to the fact that AT has its statistical data combined in this tax in three years.

Then, and bearing in mind that the final consumers of this sector of "Accommodation, Restaurants and Similar", which include tourists par excellence, support "Value Added Tax - VAT on all their purchases, we will make another analysis which will affect the collection of VAT made by the State in this sector of "Accommodation, Restaurants and Similar".

\section{ANALYSIS OF CORPORATE INCOME TAX}

The first aspect of our analysis focuses on the "Accommodation, Restaurants and Similar" activities carried out in Portugal by business companies, and that is to say, they are par excellence the legal organizational form used by entrepreneurs in the national panorama of economic actors that are dedicated to those activities.

\subsection{Analysis of the number of annual income tax returns subject to Corporate Income Tax}

Based on the statistical elements contained in the database of the „Tax and Customs Authority - AT”, consultable on its website under the title „Statistics” and in the entry "Statistics of IR", and in the case that interests here in „, Corporate Income Tax" - "2016/2018”-"Declarations mod. 22 - fiscal years 2016/2018" (Autoridade Tributária e Aduaneira - AT - https://info.portaldasfinancas.gov.pt/pt/dgci/divulgacao/estatisticas/estatisticas_ir/Pages/Estatisticas_IRC.aspx) we will make a comparative analysis between the total number of annual income tax returns of 
the Corporate Income Tax, (João Ricardo Catarino \& Vasco Branco Guimarães, 2018, p. 293) presented by all companies in Portugal and those that only dedicate themselves to the activity of "Accommodation, Restaurants and Similar" - Table 4.

Table 4. Annual Income Statements of Corporate Income Tax - Global Total

\begin{tabular}{|l|c|c|c|c|c|c|}
\hline Designation/Year/Percentage & $\mathbf{2 0 1 6}$ & $\mathbf{\%}$ & $\mathbf{2 0 1 7}$ & $\mathbf{\%}$ & $\mathbf{2 0 1 8}$ & $\mathbf{\%}$ \\
\hline Accommodation, Restaurants and Similar & 41070 & $8,8 \%$ & 42911 & $9,0 \%$ & 45314 & $9,2 \%$ \\
\hline Global Total & 464780 & $100,0 \%$ & 475119 & $100,0 \%$ & 492935 & $100,0 \%$ \\
\hline
\end{tabular}

Source: Autoridade Tributária e Aduaneira - AT - Website https://info.portaldasfinancas.gov.pt/pt/ dgci/divulgacao/estatisticas/estatisticas_ir/Pages/Estatisticas_IRC.aspx

Table 4 shows us two important facts. Firstly, it appears that there is about nine percent of all companies that carry out the activity "Accommodation, Restaurants and Similar" and, through this aspect, has the potential to be linked to tourism. Secondly, we find that in those three years there was an increase of $0.2 \%$ in business companies.

Despite this total number, not all of the declarations presented mean that the taxpayers of those activities have had taxable profit, that is, we have companies that have presented "tax losses" (João Ricardo Catarino \& Vasco Branco Guimarães, 2018, p. 347) and others that had "tax profit", that is, that had earnings that were effectively subject to the Corporate Income Tax, that is, they had "taxable income" (José Casalta Nabais, 2011, p. 570).

It is therefore important to know, among that totality of companies, which were the ones that in the end submitted annual income tax returns in those two situations. Let's see then - Table 5.

Table 5. Annual Income Tax Returns - of Corporate Income Tax - with "Tax Loss"

\begin{tabular}{|l|c|c|c|c|c|c|}
\hline Designation/Year/Percentage & $\mathbf{2 0 1 6}$ & $\mathbf{\%}$ & $\mathbf{2 0 1 7}$ & $\mathbf{\%}$ & $\mathbf{2 0 1 8}$ & $\mathbf{\%}$ \\
\hline Accommodation, Restaurants and Similar & 18034 & $12,6 \%$ & 17185 & $12,0 \%$ & 18513 & $12,2 \%$ \\
\hline Global Total & 143202 & $100,0 \%$ & 143633 & $100,0 \%$ & 152001 & $100,0 \%$ \\
\hline
\end{tabular}

Source: Autoridade Tributária e Aduaneira - AT - Webiste https://info.portaldasfinancas.gov.pt/pt/ dgci/divulgacao/estatisticas/estatisticas_ir/Pages/Estatisticas_IRC.aspx

It should be noted that among all the companies that had "Tax Losses", about $12 \%$ - twelve percent - of them were dedicated to the activity of "Accommodation, Restaurants and Similar". If from here we start to analyze companies whose annual income tax returns had "tax profit" effectively taxed, that is, their income was effectively subject to Corporate Income Tax, that is, they had "taxable income", then we have the following - Table 6.

Table 6. Annual Income Tax Returns - of Corporate Income Tax - with "Taxable Income"

\begin{tabular}{|l|c|c|c|c|c|c|}
\hline Designation/Year/ Percentage & $\mathbf{2 0 1 6}$ & $\mathbf{\%}$ & $\mathbf{2 0 1 7}$ & $\mathbf{\%}$ & $\mathbf{2 0 1 8}$ & $\mathbf{\%}$ \\
\hline Accommodation, Restaurants and Similar & 15660 & $6,9 \%$ & 18393 & $7,6 \%$ & 19580 & $7,8 \%$ \\
\hline Global Total & 228095 & $100,0 \%$ & 240690 & $100,0 \%$ & 251113 & $100,0 \%$ \\
\hline
\end{tabular}

Source: Autoridade Tributária e Aduaneira - AT - Website https://info.portaldasfinancas.gov.pt/pt/ dgci/divulgacao/estatisticas/estatisticas_ir/Pages/Estatisticas_IRC.aspx

In order to better understand the number of companies that actually had "taxable income" and to differentiate them from those that "tax loss" or "neutral tax income", we designed a summary table-Table 7. 
Table 7. Annual Income Tax Returns - of Corporate Income Tax - Summary Table

\begin{tabular}{|l|c|c|c|c|c|c|}
\hline \multicolumn{7}{|c|}{ Accommodation, Restaurant and Similar } \\
\hline \multicolumn{1}{|c|}{ Designation/Year } & $\mathbf{2 0 1 6}$ & $\mathbf{\%}$ & $\mathbf{2 0 1 7}$ & $\mathbf{\%}$ & $\mathbf{2 0 1 8}$ & $\mathbf{\%}$ \\
\hline Global Total of the Statements & 41070 & 100 & 42911 & 100 & 45314 & 100 \\
\hline With "Taxable Income" & 15660 & $38,1 \%$ & 18393 & $42,9 \%$ & 19580 & $43,2 \%$ \\
\hline With "Fiscal Loss" & 18034 & $43,9 \%$ & 17185 & $40,0 \%$ & 18513 & $40,9 \%$ \\
\hline With "Null Taxable Income" & 7376 & $18,0 \%$ & 7333 & $17,1 \%$ & 7221 & $15,9 \%$ \\
\hline
\end{tabular}

Source: Autoridade Tributária e Aduaneira - AT - Website https://info.portaldasfinancas.gov.pt/pt/ dgci/divulgacao/estatisticas/estatisticas_ir/Pages/Estatisticas_IRC.aspx

Something catches our attention in this Table. In fact, less than half of those societies had "taxable income", that is, in reality it varied between a percentage of $38.1 \%$ to $43.2 \%$.

\subsection{Analysis of net income for the years subject to Corporate Income Tax - Amounts in millions of Euro}

Having arrived here, it is now important to know the effective accounting results and necessary corrections allowed by tax legislation and concretized on the accounting result, in order to know effectively in what monetary values those "tax losses" and the concrete "taxable amounts" were effectively generated Corporate Income Tax. Let us start by quantifying the amounts included in the annual income tax returns and which have been translated into "tax losses" - Table 8.

Table 8. Amounts declared in "Tax Losses" - in millions of Euros

\begin{tabular}{|l|c|c|c|c|c|c|}
\hline Designation/Year/ Percentage & $\mathbf{2 0 1 6}$ & $\mathbf{\%}$ & $\mathbf{2 0 1 7}$ & $\mathbf{\%}$ & $\mathbf{2 0 1 8}$ & $\mathbf{\%}$ \\
\hline Accommodation, Restaurants and Similar & 505 & $3,5 \%$ & 467 & $4,6 \%$ & 447 & $3,6 \%$ \\
\hline Global Total & 14307 & $100,0 \%$ & 10065 & $100,0 \%$ & 12336 & $100,0 \%$ \\
\hline
\end{tabular}

Source: Autoridade Tributária e Aduaneira - AT - Webiste https://info.portaldasfinancas.gov.pt/pt/ dgci/divulgacao/estatisticas/estatisticas_ir/Pages/Estatisticas_IRC.aspx

If we move from here to those companies that in their annual income declarations declared "Taxable Matter" and therefore effectively calculated a corporate income tax, then we have the following table that shows the real values, namely - Table 9.

Table 9. Amounts declared in "Taxable Matter" - in millions of Euros

\begin{tabular}{|l|c|c|c|c|c|c|}
\hline Designation/Year/ Percentage & $\mathbf{2 0 1 6}$ & $\mathbf{\%}$ & $\mathbf{2 0 1 7}$ & $\mathbf{\%}$ & $\mathbf{2 0 1 8}$ & $\mathbf{\%}$ \\
\hline Accommodation, Restaurants and Similar & 656 & $3,1 \%$ & 917 & $4,0 \%$ & 1066 & $4,3 \%$ \\
\hline Global Total & 21403 & $100,0 \%$ & 22746 & $100,0 \%$ & 24984 & $100,0 \%$ \\
\hline
\end{tabular}

Source: Autoridade Tributária e Aduaneira - AT - Website https://info.portaldasfinancas.gov.pt/pt/ dgci/divulgacao/estatisticas/estatisticas_ir/Pages/Estatisticas_IRC.aspx

Table 9 shows us that these "Accommodation, Restaurants and Similar" activities generated "Collectible Matter" values that varied between 656 million Euros and 1.066 million Euros and that, although slowly, has been growing percentage when we do it in relation to the total values.

\subsection{Analysis of Corporate Income Tax effectively calculated - Amounts in millions of Euros}

Once here, it is important to know how many companies those are that effectively liquidated Corporate Income Tax, that is, among all those that submitted their annual income tax returns, which were those that effectively endured final tax. 
Our analysis focuses on two aspects. First, we will analyze the total number of declarations, and then we will analyze the monetary value in which this charge was translated. Let us examine, then, the quantification of the declarations that contained settled Corporate Income Tax - Table 10.

Table 10. Annual income tax returns with "settled Corporate Income Tax"

\begin{tabular}{|l|c|c|c|c|c|c|}
\hline Designation/Year/ Percentage & $\mathbf{2 0 1 6}$ & $\mathbf{\%}$ & $\mathbf{2 0 1 7}$ & $\mathbf{\%}$ & $\mathbf{2 0 1 8}$ & $\mathbf{\%}$ \\
\hline Accommodation, Restaurants and Similar & 10800 & $6,6 \%$ & 12988 & $7,4 \%$ & 14632 & $7,8 \%$ \\
\hline Global Total & 162824 & $100,0 \%$ & 175151 & $100,0 \%$ & 188463 & $100,0 \%$ \\
\hline
\end{tabular}

Source: Autoridade Tributária e Aduaneira - AT - Website https://info.portaldasfinancas.gov.pt/pt/ dgci/divulgacao/estatisticas/estatisticas_ir/Pages/Estatisticas_IRC.aspx

Table 10 under analysis shows us that there has been a growing number of companies that present their annual income tax returns in which they effectively liquidate Corporate Income Tax, that is, in which they effectively present a Corporate Income Tax result in favor of the State. If we start from here for the effective quantification of the Corporate Income Tax that is calculated in those statements, we now have the following Table 11.

Table 11. The total value of "settled Corporate Income Tax" - "Collection" - in millions of Euros

\begin{tabular}{|l|c|c|c|c|c|c|}
\hline Designation/Year/ Percentage & $\mathbf{2 0 1 6}$ & $\mathbf{\%}$ & $\mathbf{2 0 1 7}$ & $\mathbf{\%}$ & $\mathbf{2 0 1 8}$ & $\mathbf{\%}$ \\
\hline Accommodation, Restaurants and Similar & 115 & $2,7 \%$ & 166 & $3,7 \%$ & 200 & $4,0 \%$ \\
\hline Total of Corporate Income Tax settled & 4333 & $100,0 \%$ & 4493 & $100,0 \%$ & 4991 & $100,0 \%$ \\
\hline
\end{tabular}

Source: Autoridade Tributária e Aduaneira - AT - Website https://info.portaldasfinancas.gov.pt/pt/ dgci/divulgacao/estatisticas/estatisticas_ir/Pages/Estatisticas_IRC.aspx

\subsection{Analysis of the average Corporate Income Tax rate effectively applied}

After knowing how many "Accommodation, Restaurants and Similar" companies actually contributed to the expenses of the Portuguese State budget with Corporate Income Tax and also knowing the total monetary values of this contribution, it remains now to identify the effective average rate that represents this contribution in the overall calculation.

If we look at Table 12, below, we find out that the "general average rate" of all Taxable Persons in IRC and which results from the division of the total paid IRC and the income of those companies that were subject to Corporate Income Tax, was between $20.1 \%$ and $21.4 \%$, however, from that same Table we learn that the companies dedicated to "Accommodation, Restaurants and Similar", contributed with a weighted average rate lower than the general average, that is, for the companies engaged in this activity, the "average effective rate" varied between $20.5 \%$ and $20.8 \%$, which means that they were below those between $0.4 \%$ and $0.6 \%$ in the years 2016 and 2018, however in the fiscal year 2017 these companies endured an "average effective rate" $0.4 \%$ higher than that which was the general average.

Table 12. Corporate Income Tax "Average" effectively supported by the taxable persons

\begin{tabular}{|l|c|c|c|}
\hline Designation/Year/Percentage & $\mathbf{2 0 1 6}$ & $\mathbf{2 0 1 7}$ & $\mathbf{2 0 1 8}$ \\
\hline Accommodation, Restaurants and Similar & $20,8 \%$ & $20,5 \%$ & $20,7 \%$ \\
\hline Global Average Tax & $21,4 \%$ & $20,1 \%$ & $21,1 \%$ \\
\hline
\end{tabular}

Source: Autoridade Tributária e Aduaneira - AT - Website https://info.portaldasfinancas.gov.pt/pt/ dgci/divulgacao/estatisticas/estatisticas_ir/Pages/Estatisticas_IRC.aspx 


\section{ANALYSIS OF VALUE ADDED TAX - VAT}

In the Portuguese legal system, there is a general consumption tax (Jónatas E.M. Machado \& Paulo Nogueira da Costa, 2016, p. 374), which is nothing more than an indirect taxation system, that is, it is a tax that intends to tax final consumption.

\subsection{The importance of VAT in the Global State Budget}

If we take into account the total final value of the VAT entered in the State Accounts (Autoridade Tributária e Aduaneira - https://info.portaldasfinancas.gov.pt/pt/dgci/divulgacao/estatisticas/IVA/Pages/default.aspx) and that with it the State effectively met budgetary expenditures, we see in Table 13 that VAT is the tax that contributes the most to the State budget, as it represented in $2011-2019$ between $36.5 \%$ to $39.9 \%$ of the total of the tax revenue actually collected.

Table 13. VAT revenue that entered into the General State Account

\begin{tabular}{|c|c|c|c|}
\hline Year & VAT / Millions of Euros & \% of Total Tax Revenue & \% of GDP \\
\hline $\mathbf{2 0 1 1}$ & 13051,6 & 38,0 & 7,4 \\
\hline $\mathbf{2 0 1 2}$ & 12800,1 & 39,9 & 7,6 \\
\hline $\mathbf{2 0 1 3}$ & 13249,1 & 36,5 & 7,8 \\
\hline $\mathbf{2 0 1 4}$ & 13812,3 & 37,2 & 8,0 \\
\hline $\mathbf{2 0 1 5}$ & 14844,3 & 38,2 & 8,3 \\
\hline $\mathbf{2 0 1 6}$ & 15082,5 & 37,5 & 8,1 \\
\hline $\mathbf{2 0 1 7}$ & 16001,4 & 37,9 & 8,2 \\
\hline $\mathbf{2 0 1 8}$ & 16670,3 & 37,6 & 8,2 \\
\hline $\mathbf{2 0 1 9}$ & 17843,1 & 38,8 & 8,4 \\
\hline
\end{tabular}

Source: Autoridade Tributária e Aduaneira Website https:/info.portaldasfinancas.gov.pt/pt/ dgci/divulgacao/estatisticas/IVA/Pages/default.aspx

\subsection{The importance of "Accommodation, Restaurant and Similar activities" in VAT collection}

Considering the fact that we mentioned above, the VAT that consumers pay when using "Accommodation, restaurants and similar services" is of greater importance, fitting here, par excellence, all tourist activity, whether internal or international.

Table 14.

\begin{tabular}{|c|c|c|c|c|c|}
\hline \multirow{2}{*}{ Year } & \multicolumn{2}{|c|}{$\begin{array}{c}\text { TOTAL of "Gross Revenue" of } \\
\text { VAT / From VAT to national level }\end{array}$} & \multicolumn{2}{|c|}{$\begin{array}{c}\text { TOTAL of "Gross Revenue" of VAT } \\
\text { "Accommodation, restaurants and similar" }\end{array}$} \\
\cline { 2 - 6 } & $\begin{array}{c}\text { Millions of } \\
\text { Euros }\end{array}$ & $\begin{array}{c}\text { Year-on-year of } \\
\text { change in \% }\end{array}$ & $\begin{array}{c}\text { Millions of } \\
\text { Euros }\end{array}$ & $\begin{array}{c}\text { Year-on-year of } \\
\text { change in \%oncerning }\end{array}$ & $\begin{array}{c}\text { \%o the National } \\
\text { Total }\end{array}$ \\
\hline $\mathbf{2 0 1 1}$ & 17499,8 & 5,5 & 299,8 & $-3,4$ & $1,7 \%$ \\
\hline $\mathbf{2 0 1 2}$ & 17328,4 & $-1,0$ & 591,2 & 97,2 & $3,4 \%$ \\
\hline $\mathbf{2 0 1 3}$ & 17471,8 & 0,8 & 618,2 & 4,6 & $3,5 \%$ \\
\hline $\mathbf{2 0 1 4}$ & 17931,7 & 2,6 & 676,3 & 9,4 & $3,8 \%$ \\
\hline $\mathbf{2 0 1 5}$ & 18494,4 & 3,1 & 764,0 & 13,0 & $4,1 \%$ \\
\hline $\mathbf{2 0 1 6}$ & 19228,8 & 4,0 & 639,3 & $-16,3$ & $3,3 \%$ \\
\hline $\mathbf{2 0 1 7}$ & 20698,1 & 7,6 & 507,6 & $-20,6$ & $2,5 \%$ \\
\hline $\mathbf{2 0 1 8}$ & 22579,1 & 9,1 & 564,6 & 11,2 & $2,5 \%$ \\
\hline $\mathbf{2 0 1 9}$ & 23939,2 & 6,0 & 636,8 & 12,8 & $2,7 \%$ \\
\hline
\end{tabular}

Source: Autoridade Tributária e Aduaneira Website https://info.portaldasfinancas.gov.pt/pt/dgci/divulgacao/estatisticas/IVA/Pages/default.aspx 
If we look at Table 14, we see that in the last nine years the tax revenue generated by VAT has ranged between $1.7 \%$ to $4.1 \%$ of the total VAT charged at the national level, representing monetary values ranging from 299.8 to 764,0 million Euros.

It should be noted, for example, that VAT revenue in this sector had a growth rate in the years 2018 and 2019 of $11.2 \%$ and $12.8 \%$, respectively, which demonstrates the importance of tourism.

\subsection{The weighted average VAT rate applied at the national level}

Finally, here is one more statistic - "Table 15", which, despite not being exclusively related to tourism, as it is related to all business activity, whether, in the primary, secondary or tertiary sectors, the weighted average rate VAT effectively applied to all activities, fluctuated in the years 2011 to 2018 , between $16.4148 \%$ to $18.5932 \%$.

Table 15.

\begin{tabular}{|l|l|}
\hline Year & National weighted average rate \\
\hline $\mathbf{2 0 1 1}$ & $16,4148 \%$ \\
\hline $\mathbf{2 0 1 2}$ & $18,3625 \%$ \\
\hline $\mathbf{2 0 1 3}$ & $18,5932 \%$ \\
\hline $\mathbf{2 0 1 4}$ & $18,0073 \%$ \\
\hline $\mathbf{2 0 1 5}$ & $17,6004 \%$ \\
\hline $\mathbf{2 0 1 6}$ & $17,5835 \%$ \\
\hline $\mathbf{2 0 1 7}$ & $17,0360 \%$ \\
\hline $\mathbf{2 0 1 8}$ & $16,9947 \%$ \\
\hline & It's not determinated yet. \\
\hline
\end{tabular}

Source: Autoridade Tributária e Aduaneira Website https://info.portaldasfinancas.gov.pt/pt/dgci/divulgacao/estatisticas/IVA/Pages/default.aspx

\section{CONCLUSION}

The data collected from national statistical sources demonstrate beyond doubt that the Corporate Income Tax generated by tourism has been growing steadily, already representing a value of $4 \%$ of the national total.

On the other hand, the VAT generated by the "Tourism Industry" has also had equally sustained growth, and that growth in 2019 is already $12.8 \%$ compared to the previous year.

Faced with these data, the conclusion can only be one. Tourism, in addition to representing an important source of revenue in the Portuguese balance of exports and imports, is also a good source of tax collection for Portugal's annual budget.

\section{REFERENCES}

Autoridade Tributária e Aduaneira - Estatísticas do IRC - https://info.portaldasfinancas.gov.pt/pt/ dgci/divulgacao/estatisticas/estatisticas_ir/Pages/Estatisticas_IRC.aspx

Autoridade Tributária e Aduaneira - Estatísticas do IVA - https://info.portaldasfinancas.gov.pt/pt/ dgci/divulgacao/estatisticas/IVA/Pages/default.aspx

Instituto Nacional de Estatística - Estatísticas do Turismo: 2019. Lisboa: INE, 2020. Disponível na www url:https://www.ine.pt/xurl/pub/133574 ISSN 0377-2306. ISBN 978-989-25-0542-8 
J.J. Gomes Canotilho \& Vital Moreira (2007). CRP - Constituição da República Portuguesa, anotada - Volume I. Portugal: Coimbra Editora.

João Ricardo Catarino \& Vasco Branco Guimarães (2018). Lições de Fiscalidade - Volume I Princípios Gerais e Fiscalidade Interna. Coimbra, Portugal: Almedina

Jónatas E.M. Machado \& Paulo Nogueira da Costa (2016). Manual de Direito Fiscal - Perspetiva Multinivel. Coimbra, Portugal: Almedina

José Casalta Nabais (2011). Direito Fiscal. Coimbra, Portugal: Almedina

José Joaquim Teixeira Ribeiro (1997). Lições de Finanças Públicas - 5. ${ }^{a}$ Edição, Refundida e Atualizada. Portugal: Coimbra Editora

PORDATA - https://www.pordata.pt/DB/Portugal/Ambiente+de+Consulta/Tabela 
